\title{
ANZAAS north of Capricorn looks to its neighbours
}

Townsville, Queensland

THIS year's meeting of ANZAAS (Australian and New Zealand Association for the Advancement of Science) at the end of August was no worse for being roughly half as big as in previous years. Moreover, the meeting successfully broke with the diffuse pattern of previous years, concentrating instead on the theme of science and life in the tropics.

Unlike previous ANZAAS meetings, this year's also reflected the character of its host university - James Cook University, Australia's only university north of the Tropic of Capricorn with a modest (by Australian standards) student body of 4,000 and only 300 academics. Since its foundation in 1965, James Cook has been conscious of its responsibility (and of the political need) to interact (and to be seen to interact) with its regional community, not merely the third of Australia within the tropics but also Australia's northern neighbours.

This explains why most of the papers read at the meeting dealt with tropical research - tropical rain forests, cyclones, the exotic dangerous animals and venoms of northern Australia, aboriginal health and welfare, women living in isolation and the anthropology of this tropical region.

James Cook's regional interests are beginning to yield benefits. Professor Ray Golding, the chemist who is the university's vice-chancellor for this year, says that he had no difficulty in raising $\mathrm{A} \$ 4$ million from the travel and tourism industry to found Australia's first chair in tourism. The university is also committed to establishing a centre for tropical health and medicine and an institute for tropical rain-forest studies. (The long-established Centre for Tropical Marine Studies already has an international reputation.)

As always, ANZAAS attracted a larger throng of reporters than any other science meeting in Australia, whence one of this year's controversies - the wide coverage given to the personal assertions of Dr Robert Endean, a zoologist at the University of Queensland (Brisbane) that the infestation of the Great Barrier Reef by the Crown of Thorns starfish (Acanthaster planci) is the result of increased fishing for the natural predators of the starfish, the giant triton and the groper.

Although Endean has been publicizing his human-cause theory for the past 20 years, it was eagerly taken up as new. By comparison, the contradictory evidence presented at the meeting, much of it original, that these infestations are not new, having recurred in cycles for at least the past 2,000 years, was conveyed to the wider public as if it were a conservative and institutionally defensive response to an environmental threat.

This illustrates one of the still-recurring faults of ANZAAS. Because speakers are not required to produce a full paper in advance, and because the proceedings are not published, there is no opportunity for proper peer-criticism of the theories put forward at individual meetings. In the event, when challenged here, Endean admitted that the evidence for his theory is only circumstantial, but the pressure remains on politicians to provide funds for the eradication of starfish from the Great Barrier Reef.

True to form for ANZAAS, there was no meaningful discussion at this year's meeting of the condition of Australian science, made even more perilous by the de facto demotion of Mr Barry Jones, the minister for science.

Peter Pockley

\section{Indian nuclear power goes public}

\section{New Delhi}

NuCleAr power generation is to go public with the passing of a bill in the Indian parliament. The new company, Nuclear Power Corporation of India Limited (NPCIL), will be responsible for the design, construction and operation of atomic plants. These functions are at present carried out by the Nuclear Power Board, a wing of the Department of Atomic Energy, which will be abolished.

According to Mr K.R.Narayanan, the Science Minister, the main reason for setting up the company is shortage of government funds to support the proposed expansion of the nuclear power programme. The plan is to increase nuclear power capacity from the present
$1,230 \mathrm{MW}$ to $10,000 \mathrm{MW}$ by the year 2000 . The estimated cost is more than $\$ 10,000$ million, which obviously cannot come from budgetary allocations. The NPCIL will raise the money from banks, financial institutions and by floating tax-exempt bonds in the capital markets. It is expected that the company will become financially self-reliant by 1995 and not require budgetary support after that.

The NPCIL will work closely with state electricity boards, which will purchase the nuclear electricity, and will depend on the Bhabha Atomic Research Centre for research and development. The anti-nuclear lobby hopes for greater accountability from NPCIL. K.S.Jayaraman
Test without EPA approval has come to an end

\section{Washington}

AN experiment involving environmental release of genetically modified microorganisms that began without US Environmental Protection Agency (EPA) approval came to an end last week. Gary Strobel, a Montana State University researcher, cut down and burned the elm trees he had injected with a modified strain of bacteria to protect them against Dutch elm disease. He said he ended the experiment because it might be a stain on the university's reputation, and he did not want to jeopardize his colleagues' work.

The EPA has issued "mild sanctions" against Strobel for flouting the regulations governing the field-testing of modified microorganisms. Strobel failed to get EPA approval before injecting 14 trees on campus in June with a strain of Pseudomonas syringae that he had modified to enhance its ability to produce an antibiotic that wards off Dutch elm disease. EPA regulations require researchers to seek approval from the agency $\mathbf{9 0}$ days before

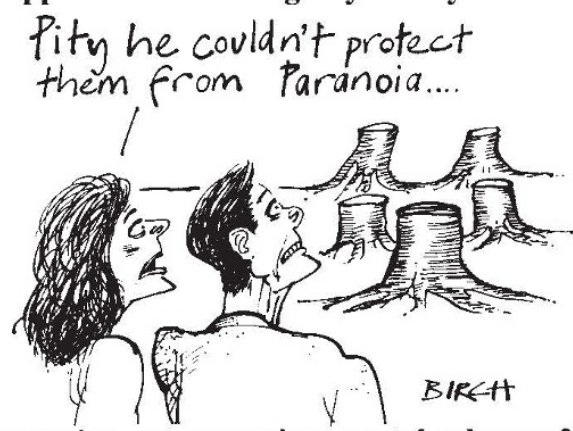

carrying out an environmental release of modified microorganisms. But waiting for EPA approval would have meant postponing the experiment to next year's growing season, so Strobel began injecting trees several days after he mailed his application to the EPA. For the next year, EPA sanctions require Strobel to have a "responsible party" cosponsor any field tests of recombinant organisms. In addition, he will have to seek approval from the university's biosafety committee.

Strobel's actions have raised doubts within the scientific community. Many feel that his actions were unwarranted because he sidestepped the peer-review process that forms the backbone of science. Others are concerned that the widespread publicity of the case endangers the nascent "goodwill" toward biotechnology held by the general public, and weakens the public's faith in the government's ability to regulate new technologies. But the federal rules governing biotechnology are reckoned to be complex and disjointed, weaknesses highlighted by Strobel's defiance. Carol Ezzell 